\title{
Hubungan Pemberian Mp-Asi Pada Bayi Usia 0-6 Bulan Dengan Terjadinya Diare Di Desa Pacet Kecamatan Pacet Kabupaten Mojokerto
}

\author{
Veryudha Eka P*, Lutfi wahyuni**Indria Kusuma Putri*** \\ *)Veryudha Eka P Stikes Bina Sehat PPNI Mojokerto \\ **)Lutfi wahyuni Stikes Bina Sehat PPNI Mojokerto \\ ***) Indria Kusuka Putri Stikes Bina Sehat PPNI Mojokerto
}

\begin{abstract}
Complementary feeding (MP-ASI) was food and beverage contain of nutrients, which gave to infants or children age 6-24 months in order to meet the nutritional needs in addition to breast milk. The incidence of diarrhea in infants can be caused due to errors in feeding, where the baby has been feed than breast milk before the age of 6 months. This study aimed to analyze the relationship between the give complementary feeding in baby age 0-6 months with incidence diarrhea at the Pacet Village, Pacet District, Mojokerto. The research of the population has been taken from all baby 0-6 months at the Pacet Village, Pacet District, Mojokerto. And got the sample from 42 respondents with techniq of gotten the sample was Total Sampling. That was calling a retrospective research. Meanwhile processing data analysis was using coding, scoring, tabulating, and cross tabulation. Based on the result, it was showing that A Corellation of Giving Complementary Feeds (MPASI) to baby 0-6 months with incidence diarrhea in Pacet Village Pacet District Mojokerto. Feeding companion early breastfeeding can cause interference with absorption in the intestine due to the baby's digestive system is less than 6 months old and has not been perfect. Malabsorption that occurs will cause osmotic pressure in intestinal cavity increases resulting in a shift of water and electrolytes into gut cavity would which result diarrhea.
\end{abstract}

Keywords: breast milk, baby 0-6 months, the incidence of diarrhea

\section{Pendahuluan}

Makanan pendamping ASI (MP-ASI) adalah makanan dan minuman yang mengandung zat gizi, yang diberikan pada bayi atau anak yang berusia 6-24 bulan guna memenuhi kebutuhan gizi selain ASI (Maryunani, 2010). Makanan pendamping ASI diperkenalkan untuk memenuhi kebutuhan bayi yang makin meningkat karena bayi membutuhkan zat-zat gizi yang semakin tinggi untuk pertumbuhan dan perkembangan. Kebiasaan di masyarakat, seorang ibu seringkali memberikan makanan padat kepada bayi yang berumur beberapa hari atau beberapa minggu seperti memberikan nasi yang dihaluskan atau pisang.

WHO menyatakan bahwa pada tahun 2011, 3.9 juta balita meninggal dunia dan 19\% diantaranya dikarenakan diare. Diare adalah frekuensi buang air besar yang lebih dari 4 kali pada bayi dan lebih dari 3 kali pada anak, konsistensi feces encer, dapat berwarna hijau, atau dapat pula bercampur lendir dan darah atau hanya lendir saja (Suraatmaja, 2007). Kejadian diare pada bayi dapat disebabkan karena kesalahan dalam pemberian makan, dimana bayi sudah diberi makan selain ASI sebelum berusia 6 bulan.

Penyakit diare kini masih merupakan salah satu penyakit utama pada bayi dan anak di Indonesia. Diperkirakan angka kesakitan dan angka kejadian diare di Indonesia berkisar diantara 150-430 per seribu penduduk setahunnya atau terjadi pada 28 orang dari 100 penduduk. Pada tahun 2011, diare pada balita berkisar 28 juta dengan kematian sebanyak 150.000 300.000 balita (Riskesdas, 2011).

Berdasarkan studi pendahuluan yang dilakukan oleh peneliti pada tanggal 18 
Februari 2015 dengan teknik wawancara pada 6 ibu yang mempunyai bayi kurang dari 6 bulan, 2 bayi diberikan Asi Eksklusif, dan 4 bayi tidak ASI Eksklusif telah diberikan MP-ASI berupa bubur dan pisang, dari 4 bayi yang tidak diberikan ASI Eksklusif 3 bayi pernah mengalami diare dimana dalam sehari buang air besar (BAB) 4-5 kali dengan konsistensi encer, dan bercampur lendir lalu dibawa ke bidan, sedangkan 1 bayi lainnya tidak mengalami diare.

Pemberian MP-ASI secara dini dapat berdampak negatif bagi bayi yaitu hasil riset terakhir dari peneliti di Indonesia menunjukkan bahwa bayi yang mendapat MP-ASI sebelum ia berumur 6 bulan, lebih banyak terserang diare, sembelit, batuk-pilek, dan panas dibandingkan bayi yang hanya mendapatkan ASI Eksklusif, terjadi gangguan gastrointestinal pada bayi, alergi dan obesitas (Lituhayu, Rivanda 2008). Penelitian ini bertujuan untuk menganalisis hubungan pemberian MP-ASI pada bayi usia 0-6 bulan dengan terjadinya diare di Desa Pacet Kecamatan Pacet Kabupaten Mojokerto

\section{Metodelogi Penelitian}

Penelitian ini menggunakan desain penelitian Corelational Analitik dengan rancangan penelitian Retrospektif .

Penilitian ini dilakukan di desa Pacet kecamatan Pacet kabupaten Mojokerto yang Penelitian ini dilaksanakan pada bulan Maret 2015 sampai dengan Juni 2015.

Populasi dalam penelitian ini adalah semua bayi usia 0-6 bulan yang ada di desa Pacet kecamatan Pacet kabupaten Mojokerto yang Penelitian ini dilaksanakan pada bulan Maret 2015 sampai dengan Juni 2015.

Sampel dalam penelitian ini adalah semua bayi usia 0-6 bulan di desa Pacet kecamatan Pacet kabupaten Mojokerto yang berjumlah 42 orang.

Penelitian ini menggunakan metode pengambilan sampel yaitu non probability sampling. Non probability sampling yang di gunakan adalah tipe Sampling jenuh (Total Sampling) yaitu cara pengambilan sampel dengan mengambil semua anggota populasi menjadi sampel (Hidayat, 2007). Yaitu semua bayi usia 0-6 bulan.

\section{Hasil Penelitian}

a. Karakteristik Responden Berdasarkan Pemberian ASI

Berdasarkan tabel 1 menunjukkan bahwa dari 42 responden sebagian besar diberikan MP-ASI sebanyak 27 responden $(64,3 \%)$

b. Karakteristik Responden Berdasarkan Terjadinya Diare

Berdasarkan tabel 2 menunjukkan bahwa dari 42 responden, yang mengalami diare sebanyak 24 responden $(57,1 \%)$

c. Tabulasi Silang Hubungan Pemberian MP-ASI Pada Bayi Usia 0-6 Bulan dengan Terjadinya Diare

Berdasarkan hasil tabulasi silang pada tabel 3 menunjukkan bahwa dari 42 responden sebagian besar diberikan MP-ASI sebanyak 27 responden $(64,3 \%)$ dan sebagian besar mengalami diare sebanyak 24 responden $(57,1 \%)$. artinya Ada Hubungan Pemberian MP-ASI Pada Bayi Usia 0-6 Bulan dengan Terjadinya Diare.

a. Karakteristik

Responden Berdasarkan Pemberian ASI

Tabel 1 Distribusi Frekuensi Karakteristik Responden Berdasarkan Pemberian ASI di Desa Pacet Kecamatan Pacet Kabupaten Mojokerto Bulan Juni Tahun 2015

\begin{tabular}{llll}
\hline No & $\begin{array}{l}\text { Pemberian } \\
\text { ASI }\end{array}$ & Frekuensi & $\begin{array}{l}\text { Presentase } \\
(\%)\end{array}$ \\
\hline 1 & $\begin{array}{l}\text { Diberikan } \\
\text { ASI }\end{array}$ & 15 & 35,7 \\
2 & $\begin{array}{l}\text { Diberikan } \\
\text { MP-ASI }\end{array}$ & 27 & 64,3 \\
\hline & Jumlah & 42 & 100
\end{tabular}

Sumber : Data Primer 2015 
b. Karakteristik

Responden

Berdasarkan Terjadinya Diare

Tabel 2 Distribusi Frekuensi

Karakteristik

Responden

Berdasarkan Terjadinya Diare di

Desa Pacet Kecamatan Pacet

Kabupaten Mojokerto Bulan Juni Tahun 2015

\begin{tabular}{llll}
\hline No & $\begin{array}{l}\text { Kejadian } \\
\text { Diare }\end{array}$ & Frekuensi & $\begin{array}{l}\text { Presentase } \\
(\boldsymbol{\%})\end{array}$ \\
\hline 1 & Diare & 24 & 57,1 \\
2 & Tidak Diare & 18 & 42,9 \\
\hline & Jumlah & 42 & 100 \\
\hline
\end{tabular}

Sumber : Data Primer 2015

c. Tabulasi Silang Hubungan Pemberian MP-ASI Pada Bayi Usia 0-6 Bulan dengan Terjadinya Diare

Tabel 3 Tabulasi Silang Hubungan Pemberian MP-ASI Pada Bayi Usia 0-6 Bulan dengan Terjadinya Diare di Desa Pacet Kecamatan Pacet Kabupaten Mojokerto Bulan Juni Tahun 2015

\begin{tabular}{lllllll}
\hline \multicolumn{7}{c}{ Kejadian Diare } \\
& Diare & $\begin{array}{l}\text { Tidak } \\
\text { Diare }\end{array}$ & \multicolumn{2}{l}{ Jumlah } \\
\hline $\begin{array}{l}\text { Pemberian } \\
\text { ASI }\end{array}$ & F & $(\boldsymbol{\%})$ & F & $(\boldsymbol{\%})$ & F & $(\boldsymbol{\%})$ \\
\hline $\begin{array}{l}\text { Diberikan } \\
\text { ASI }\end{array}$ & 0 & 0 & 15 & 35,7 & 15 & 35,7 \\
$\begin{array}{l}\text { Diberikan } \\
\text { MP-ASI }\end{array}$ & 24 & 57,1 & 3 & 7,2 & 27 & 64,3 \\
\hline Jumlah & 24 & 57,1 & 18 & 42,9 & 42 & 100 \\
\hline
\end{tabular}

Sumber : Data Primer 2015

\section{Pembahasan}

Pemberian MP-ASI pada bayi usia 0-6 bulan di Desa Pacet Kecamatan Pacet Kabupaten Mojokerto

Berdasarkan tabel 1 menunjukkan bahwa sebagian besar bayi telah diberikan
Makanan Pendamping ASI (MP-ASI) sebanyak 27 responden $(64,3 \%)$.

Makanan Pendamping ASI (MP-ASI) adalah makanan tambahan yang diberikan kepada bayi setelah berusia 6 bulan sampai 24 bulan (Waryana, 2010).

Hasil riset terakhir dari peneliti di Indonesia menunjukkan bahwa bayi yang mendapat MP-ASI sebelum ia berumur 6 bulan, lebih banyak terserang diare, sembelit, batuk-pilek, dan panas dibandingkan bayi yang hanya mendapatkan ASI Eksklusif. (Lituhayu, Rivanda 2008).

Hal ini sesuai dengan hasil penelitian yang menunjukkan masih banyak responden yang diberikan MP-ASI kurang dari 6 bulan padahal MP-ASI seharusnya diberikan setelah bayi umur 6 bulan. Bayi usia 0-6 bulan seharusnya hanya diberikan ASI atau ASI Eksklusif tanpa tambahan makanan papapun.

Terjadinya diare pada bayi usia 0-6 bulan di Desa Pacet Kecamatan Pacet Kabupaten Mojokerto

Berdasarkan tabel 2 menunjukkan bahwa sebagian besar responden mengalami diare sebanyak 24 responden $(57,1 \%)$.

Menurut (Ngastiyah,2005) Diare terjadi apabila bayi buang air besar lebih encer dan lebih sering dari biasanya. Tinja anak diare dapat mengandung lendir dan darah, tergantung pada penyebabnya. Gejala lain adalah demam dan muntah. Kadang, gejala muntah dan demam mendahului gejala diarenya. Diare dapat menyebabkan kekurangan cairan.

Faktor terjadinya diare karena infeksi dari berbagai bakteri yang disebabkan oleh kontaminasi makanan maupun air minum, mal-absorbsi, makanan, dan psikologis. Diare disebabkan oleh infeksi enteral yaitu infeksi saluran pencernaan yang merupakan penyebab utama diare pada bayi. Infeksi enteral ini meliputi: infeksi bakteri, virus, dan parasit. (Hidayat,2008). 


\section{Hubungan Pemberian MP-ASI Pada Bayi Usia 0-6 Bulan dengan Terjadinya Diare}

Berdasarkan hasil tabulasi silang pada tabel 3 menunjukkan bahwa paling banyak adalah responden diberikan MPASI dan mengalami diare yaitu sebanyak 24 responden $(57,1 \%)$ yang artinya Ada Hubungan Pemberian MP-ASI Pada Bayi Usia 0-6 Bulan dengan Terjadinya Diare.

Pemberian makanan tambahan selain ASI pada bayi kurang dari 6 bulan akan memberikan efek negative pada bayi antara lain dimana tumbuh kembang bayi tidak akan maksimal, kekebalan tubuh bayi kurang, bayi mengalami konstipasi dan diare, serta adanya reaksi alergi (Depkes RI, 2012).

Pemberian Makanan Pendamping ASI dini dapat menyebabkan terjadinya gangguan absorbsi dalam usus karena sistem pencernaan bayi yang berusia kurang dari 6 bulan belum sempurna dan Makanan Pendamping (MP-ASI) mengandung konsentrasi tinggi berbagai zat makanan. Malabsorbsi yang terjadi akan menyebabkan tekanan osmotik dalam rongga usus meningkat sehingga terjadi pergeseran air dan elektrolit ke dalam rongga usus maka timbul diare (Hidayat, 2008)

\section{Kesimpulan}

Sebagian besar bayi usia 0-6 bulan di Desa Pacet Kecamatan Pacet Kabupaten Mojokerto diberikan MP-ASI yaitu sebanyak 27 responden $(64,3 \%)$

Sebagian besar bayi usia 0-6 bulan mengalami diare yaitu sebanyak 24 responden $(57,1 \%)$.

Ada hubungan pemberian makanan pendamping ASI (MP-ASI) pada bayi usia 0-6 bulan dengan terjadinya diare di Desa Pacet Kecamatan Pacet Kabupaten Mojokerto. Pemberian MP-ASI sebelum usia 6 bulan dapat menyebabkan diare.

Dari hasil penelitian dapat dikatakan bahwa pemberian MP-ASI terlalu dini yaitu kurang dari 6 bulan maka akan menyebabkan terjadinya diare sedangkan pemberian ASI Eksklusif dan pemberian MP-ASI tepat waktu tidak akan menyebabkan terjadinya diare pada bayi.

\section{DAFTAR PUSTAKA}

Depkes RI. 2007. Pedoman Umum Pemberian Makanan Pendamping ASI. Diakses pada tanggal 18 Februari 2015 di website www. Depkes.org.id

Hidayat, Alimul Aziz. 2008. Pengantar Ilmu Kesehatan Anak Untuk Pendidikan Bidan,. Jakarta.Salemba Medika . 2007. Metode Penelitian Kebidanan dan Teknik Analisis Data. Jakarta: Salemba Medika

Ngastiyah.2005. Perawatan Anak Sakit. Jakarta : EGC

Suraatmaja, S. 2007. Kapita Selekta Gastroenterologi Anak. Jakarta : Sagung Seto

Waryana. 2010. Gizi Reproduksi. Yogyakarta: Pustaka Rihama 